\title{
"CARRIE FISHER SENT ME"
}

\section{Princess Leia as an avatar of resistance in the Women's March}

\section{Christina M. Knopf}

Keywords:

Star Wars, Resistance, Women's March

A January 2017 article from the Independent led with the words, "Across the world, Carrie Fisher's rebel princess turned general become [sic] a source of hope and inspiration for women everywhere" (Loughrey 2017, para. 1). The article was loaded with images from Twitter of protest signs bearing Carrie Fisher's visage with her iconic hair rolls superimposed with such slogans as "Woman's Place is in the Resistance," "We are the Resistance," and "Rebel Scum." Signs found in Twitter posts, news articles, and published archives revealed numerous Star Wars-inspired messages of feminist rebellion and resistance. Some featured Princess Leia as Rosie the Riveter, the emblem of the Resistance fighters tattooed on her arm or taking the place of Rosie's employment badge on her collar. Signs recreated the Star Wars' ITC Serif Gothic Heavy font to proclaim that "The Women Strike Back," "The Fempire Strikes Back," "The Estrogen Empire Strikes Back," and "The Female Force Awakens," others presented the Resistance insignia and/or Princess Leia's face stating "Resistance is Built on Hope." Some protestors dressed in a full Princess Leia costumes from A New Hope, promising to defeat the Dark Side. Some marchers paraphrased Leia's iconic plea to Obi Wan, and declared, "We are Our Only Hope."

A sign paraphrasing Yoda argued that "Fear leads to anger. Anger leads to hate. Hate leads to Trump." While many signs claimed that the future is female and that women run the world, one young marcher wore a Princess Leia t-shirt to say, "Girls run the galaxy." Numerous other variations of Star Wars-inspired signs moved through the streets and were spread far and wide through Twitter, thanks in part to Mark Hamill who promoted a Carrie Fisher-inspired thread saying, "I know where she stood. You know where she stood. Such an honor to see her standing with you today. Bigly. \#Resistance. \#WorldWideWomensMarch.” 


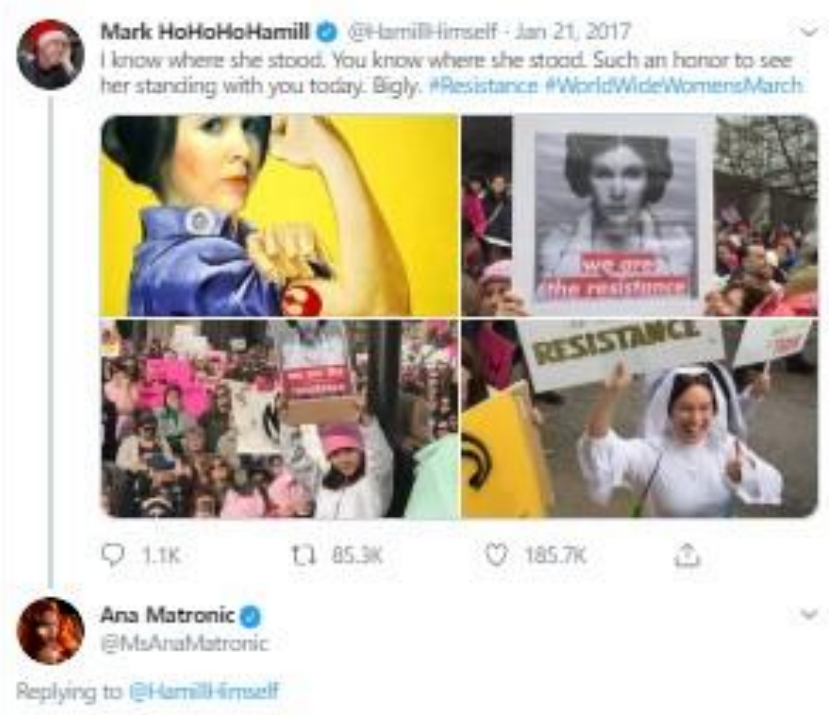

Leia was my first feminist icon. When@carrieffisher passed, I knew I had to pay tribute. This is me \& fellow marcher Quince

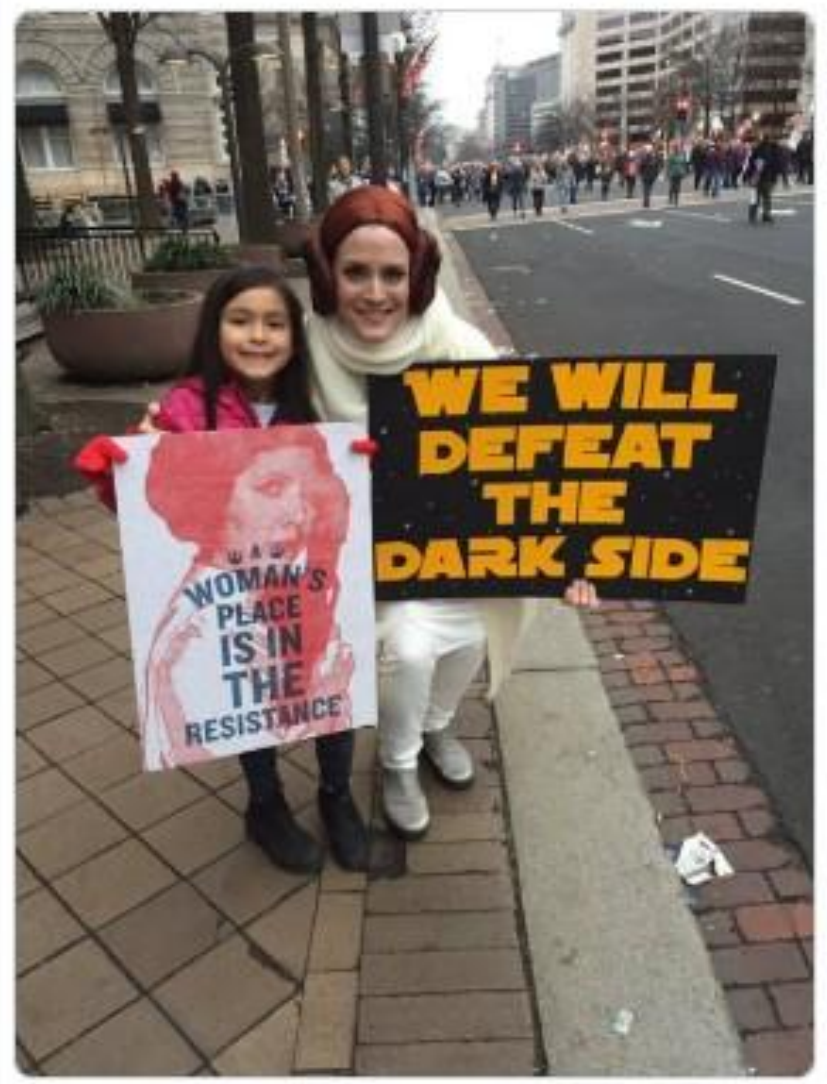

8.25 PM- $\tan 21,2017$ - Twitter for iPhone

83 Retweets 501 Likes

Figure 1: Tweets from Mark Hamill and Ana Matronic marking the January 21, 2017 Worldwide Women's March and remembering Carrie Fisher.
Some signs simply said, "Carrie Fisher sent me," while others noted "Carrie Fisher didn't have time for this sexist crap and neither do I." One Twitter user even shared an image of a protestor hoisting a photo of Slave Leia breaking free from a MAGA-hat wearing Jabba the Hutt, while another foregrounded her photos with a Princess Leia action figure - putting the mythic resistance fighter directly into the March crowds. Two years later, the trend continued. Princess Leia, now occasionally joined by the Jedi padawan Rey introduced in The Force Awakens, rebel Ahsoka Tano from Star Wars: The Clone Wars, and resistance fighter Rose Tico from The Last Jedi, again adorned signs declaring, "We are the resistance," "We are the rebellion," and "The Fempire Strikes Back."

Clarisse Loughrey, writing for The Independent, observed that the combined timing of Trump's election, Fisher's death, and the release of Rogue One, whose message was "rebellions are built on hope," merged with film's "power to inspire, rally, and comfort those who search for largerthan-life heroes to also lift them up and carry them forward" (2017, para. 3). Indeed, not only The Independent, but also Entertainment Weekly, Vox, and The Washington Post, ran stories about the political content and power of pop culture. The Post suggested that, "Pop culture gave a lot of people marching [...] the sentiments that helped the crowd seem feisty, energized and defiant, rather than defeated" and indicated that media creations of "new visions for what the world can be still matter" (Rosenberg 2017, para. 7). Vox considered the phenomenon more critically. While acknowledging that pop culture allegiances express both personal and communal identities that establish who's in and who's out (part of the rhetoric of agitation in any social movement), $\underline{V o x}$ 


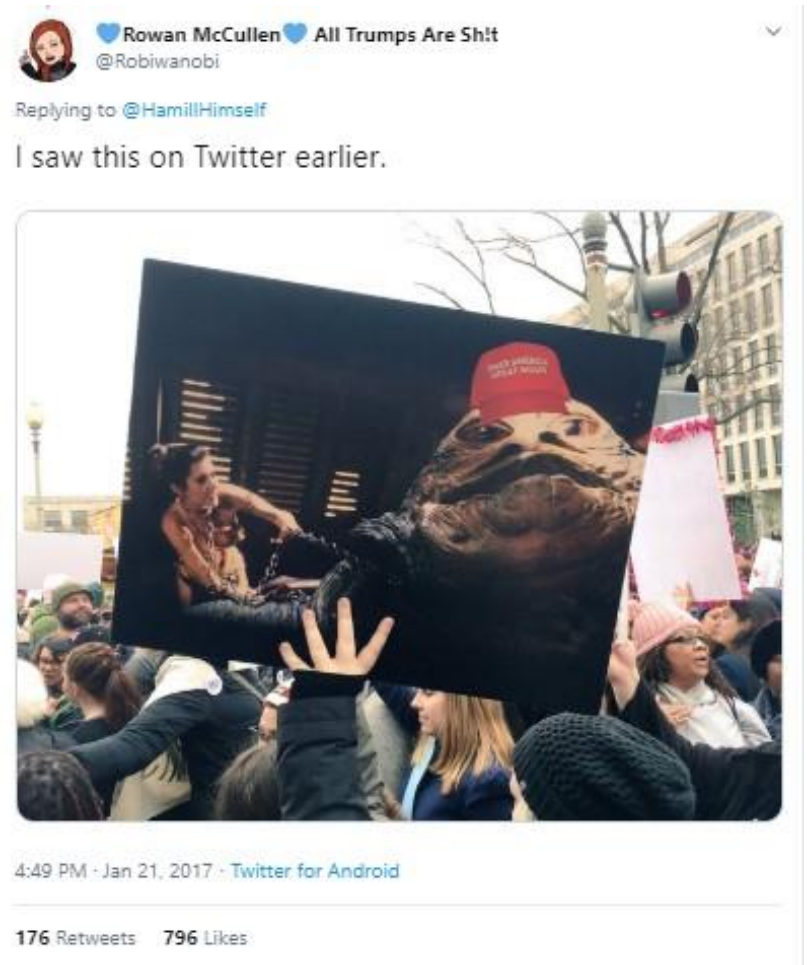

Figure 2: Twitter user @Robiwanobi responds to Mark Hammill's Tweet in Figure 1. also referred to Western Kentucky University philosophy professor Eric Bain-Selbo who argued that, "The consumer of popular culture is an isolated individual" and that these communities of identity reflect market segments rather than political ideologies (quoted in Grady 2017, para. 8). The article thus concludes that, good or bad, "The revolution will be televised. It will be broadcast on the radio. It will be discussed and furthered on the internet. It will be replicated into a thousand memes. That's how our culture builds its tribes and its groups and, now, its political protests" (Grady 2017, para. 15).

This idea, that revolution will be mediated and replicated as part of how culture builds its tribes and protests, is at the heart of this essay which discusses how the merger of protest symbols and pop culture markers work as, what Paolo Gerbaudo (2015) dubbed, memetic signifiers - iconographic "references that because of their inclusive and post-ideological content and their [...] capacity to spread with extreme rapidity, are highly conducive to processes of collective identification" (918). Collective action is the result of purposes and resources oriented within social relationships activated to create a sense of being and working together. The formation of a "we" happens by orienting the ends, means, and, significantly for the consideration of pop culture, the environment of action (Melucci 1995). That environment includes a culture of media entertainment. Active fans of such cult media franchises as Lord of the Rings, Star Trek, and Star Wars, through the participatory fandom enabled by computer-mediated-communication, are "beginning to be recognized as important contributors to formation of collective belief" because of their dedication to and their close readings, critical analyses, and personalization of pop cultural texts (Shefrin 2004, 269). Sarah Thornton argues that fan cultures construct images of the mainstream in order to produce a position of difference; they "carry around images of the social worlds that make up" the culture of their fandom. "These mental maps, rich in cultural detail and value judgement, offer them a distinct 'sense of their place' but also a sense of the other's place" $(1995,99)$.

The same processes are at work in the rhetoric of agitation that uses strategies of solidification and polarization to unite followers, create a sense of community, and produce or reinforce cohesiveness, while distinguishing between those who are group members and those who are not and may even be group enemies. Solidification tactics within social movements most frequently include the development and sharing of plays, literature, songs, rituals, slogans, symbols, and shared language (Bowers, Ochs, Jensen and Schulz 2010). Likewise, fan communities engage various modes of authorship, production, marketing, and consumption, in addition to dialoguing, role-playing, and judgement-making to establish and reinforce personal 
and global identities marked by in-groups and out-groups (Hunt 2003; Black 2009; Lyden 2012; Shefrin 2004).

\section{Carrie Fisher Sent Me}

These two worlds of authority-establishment in fandom and solidification in agitation joined forces - and The Force - with the advent of the 2017 Women's March. On January 21, 2017, an estimated "five million women from Washington DC to Dar es Salaam to Seoul" marched in towns and tundras to stand up to tyranny as part of the single largest protest in world history (Women's March Organizers 2017, 11). Liberty, women's rights, equal rights, human rights, unity, and celebrations of diverse identities were the core values of the protest, which would be repeated in 2018 and 2019 (no author 2017). In his contribution to The Ultimate Star Wars and Philosophy, Cole Bowman observed,

There's an imbalance in the Force, and it's not the one that concerns the Jedi. There's an imbalance of gender roles in everyone's favorite space saga, with the vast majority of characters played by males while the female parts are minimized at nearly every turn. But the underlying problem of womanhood in Star Wars might be even more insidious than Darth Sidious himself. It can be tough to be a woman in any universe, but perhaps it's especially so in a galaxy far, far away, where the only obvious female role models are a princess and a queen both intimately related to the dark lord trying to rule them all.

So, why is it difficult to embrace a strong female identity anywhere, let alone in the midst of intergalactic war? Women are expected to fulfill many disparate roles during their lives, so it's little surprise that there's a conflict raging within many women about who they're supposed to be in the absence of strong role models to emulate. $(2016,161$, emphasis added)

This sentiment perfectly reflects not only the gendered situation in the Star Wars universe, but the very real motivations of the Women's March.

Grassroots appropriation of Star Wars for political purposes is not a recent phenomenon. At the height of the Monica Lewinsky/President Bill Clinton scandal in the late 1990s, a digital postcard, created by MAD Magazine, proliferated on the World Wide Web that spoofed the Brothers Hildebrant's famous poster for the original release of Star Wars. In this contemporary and somewhat off-color version, Bill Clinton [in the role of Luke Skywalker] thrusts his power cigar skyward as a scantily clad Monica [standing in for Princess Leia] clings to his leg, her black thong undies barely visible through her translucent white robe. The sinister face of Ken Starr looms [as Darth Vader] ominously in the background. (Jenkins 2006, 551).

This was but one example of the political appropriation of Star Wars that surrounded the digitally enhanced re-release of the original trilogy in 1997 and the release of the first prequel, The Phantom Menace, in 1999 (Jenkins 2006). As the prequel trilogy developed throughout the 200os, Senator John McCain brandished a toy light saber on the campaign trail and compared himself to Luke Skywalker - a rebel fighting his party's "Death Star" of special interests (AzBlueMeanie 2008). More spoofs and parodies resurfaced in 2016-2019, coinciding with the releases of The Force Awakens (2015), Rogue One (2016), The Last Jedi (2017), and Solo (2018). The Week curated a list of Star Wars-themed political cartoons in 2015, featuring messages that used "The Force Awakens" to describe the Federal Reserve, that reimagined nine Republican presidential primary candidates as Star Wars characters (such as Jeb Bush as 
Chewbacca, Donald Trump as Darth Vader, and Carly Fiorina as Leia), and that cast Bernie Sanders as Yoda nonsensically declaring "Capitalism leads to anger. Anger leads to hate. Hate leads to climate change" (The Week Staff 2015). By the time Princess Leia was appearing in 2017 Women's Marches, political satire comic books used the likeness of Darth Sidious to represent corruption in American politics. Keenspot's 2017 Trump's Titans vs. Fidget Spinner Force reimagined Hillary Clinton supporter George Soros as the dark emperor while Antarctic Press's 2017 President Pence used Palpatine's grotesque visage to embody an evil leftist named "Pinkor" (Barron and Remulac 2017; Perez and Dunn 2017). Soon after, the Columbus Dispatch presented an editorial cartoon casting Trump as "The Worst Jedi." A May 2019 editorial cartoon by Nick Anderson imagined Attorney General William Barr in the role of Jabba the Hutt, enslaving a bewildered and bedraggled Lady Justice in place of Princess Leia, as commentary about Barr lying in Congressional testimony (Figure 3). Similar imagery was used in 2015 with a Jabba Trump holding the GOP, depicted as a slave elephant, captive (The Week Staff 2015). Since the 1980s, Star Wars motifs have been a recurring part of the rhetorical invention of political cartoons, used as an allusion that provides audiences with a shortcut for processing and identifying the editorial message (see, for examples, Krämer 2012; Conners 2007; Conners 2005; Lawrence 2006; Dougherty 2002; Grofman 1989).

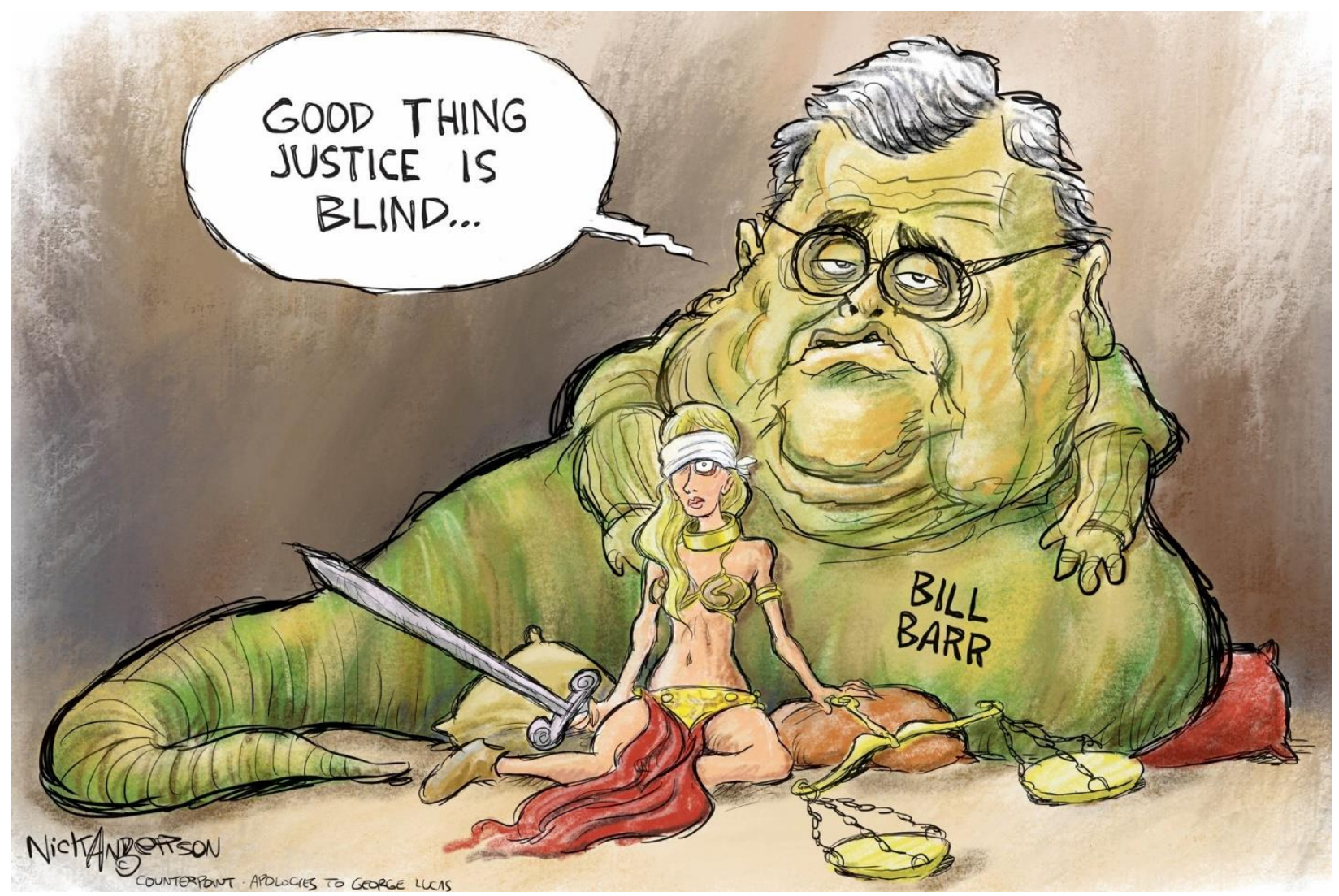

Figure 3: Editorial cartoon by Nick Anderson, May 8, 2019.

With regards to Princess Leia's appropriation by Women's Marchers, Leia is a strong woman - a leader in the Rebel Alliance who challenges not only the men who oppose her but also those who ally with her; she outshoots, outmaneuvers, and outthinks them at every turn (Bowman 2016). Significantly, she is the impetus for action. As stated during the opening crawl of Episode 
IV, "Pursued by the Empire's sinister agents, Princess Leia races home aboard her starship, custodian of the stolen plans that can save her people and restore freedom to the galaxy." Everything that happens starts with Leia's bold act of rebellion (Bowman 2016, 163). She is, therefore, a fitting icon for the resisters and the re-sisters participating in the Women's March. Furthermore, as 2017 marked the 40th anniversary of Star Wars: A New Hope, Princess Leia has been a recognizable figure in the cultural and media environment for over four decades, making her an effective memetic signifier. In analyzing the visual symbolism of the 2009 London G20 protest, Tim Liao states, "Symbolism is a powerful vehicle for social mobilization because it can bind together people in a social movement behind a common cause by helping participants self-define themselves" (2010, 37). Drawing on Bourdieu and Schudson, Liao demonstrates that symbols represent collective memory; if effective, they are retrievable or recognizable, they resonate with traditions or experiences, they have institutional retention or longevity, and they possess resolution or the ability to influence behaviors.

\section{The Fempire Strikes Back}

Brigitte Barclay (2019), in “'Rebellions are Built on Hope': Women and Star Wars,” suggests that for women who came of age during the original Star Wars trilogy, the character of Princess Leia served as both a role model and a marker of women's liberation. Leia was pop cultural proof that women's place in society was advancing and that they could assert themselves in male-dominated arenas. This image was strengthened in subsequent years by the outspoken personality of Leia actress Carrie Fisher. Moreover, Princess Leia's distinctive look in her original, A New Hope, appearance - white dress, black blaster, and twin hair buns inspired by the hairstyle of female Mexican revolutionaries - ensured her image was broadly recognizable and retrievable as that of a strong, rebellious, female in the patriarchy (Cagle 2002). In fact, as noted in a recent study by Mary C. King and Jessica L. Ridgway (2019), this iconic costuming for Leia is a marker of her position and strength. Her modest dress minimizes sexual objectification and her tightly rolled hair suggests power and control.

The influence and prevalence of Star Wars iconography in the Women's March(es) cannot, however, be attributed solely to the collective memory tied into the nostalgia, celebrity, and fashion of Leia. Indeed, a 2018 study by film studies professor Rebecca Harrison, found that $A$ New Hope was the worst movie of the franchise for female screen time (Thompson 2018). As marches continued in 2018 and beyond, the power of Star Wars as an avatar of women's resistance was reinforced, and advanced, by the presence and resonance of new, and more varied, empowered-female characters in the latest multi-media installments of the franchise characters who, according to Harrison's study, were getting far more screen time in The Last Jedi (Thompson 2018). As suggested in a Vanity Fair article previewing The Rise of Skywalker, Leia serves as a reminder to women of a certain generation how much things have and haven't changed and of rebellions gone-by, while characters like Rey and Rose resonate with the younger generations who are dealing with the failures of their predecessors (see discussion in Grossman 2019).

Appearing in the newest trilogy, the Anthology Series of stand-alone films, and the animated series, the "women of the galaxy" now include figures who are not white, are not human, are not young, and who are not warriors. As described by StarWars.com, "The women of the Star Wars universe are a diverse galaxy of heroes and villains, renegades and rogues, caretakers and, 
sometimes, unscrupulous scum" (Ratcliffe 2018, para. 1). Characters of particular note include now-General Leia Organa (who "changed her hair"), Vice Admiral Amilyn Holdo, indomitable scavenger Rey, Togruta hero of the Clone Wars, Ahsoka Tano, reformed criminal in the Rebel Alliance Jyn Erso, Resistance maintenance worker Rose Tico, wise pirate-turned-tavern owner Maz Kanata, First Order Captain Phasma, and scoundrel Zorri Bliss. Such characters point to a broadening, if not yet inclusive, perspective on not only women's roles, from innkeeper to military strategist, but also their experiences and backgrounds, both cultural and lived. Leia, as princess and rebel and general, and as the "first" female leader in the Star Wars saga, is the synecodochal figure for this growing group of galaxy women.

As an avatar of the Women's March, and most recognizable woman of the Star Wars franchise, Princess Leia "conveys one's identification with a group, satisfying the sense of belonging to a political community" and thanks to the spread via social media of her image as a symbol of women's resistance beyond the march itself the avatar taps into other fan and even mainstream communities enabling viral diffusion of collective identification (Gerbaudo 2015, 918). Protestors who chose to re-mix Leia's image with their own likeness through cosplay, with David Bowie's image (by giving Leia Ziggy Stardust face-paint), or with Rosie the Riveter's image, particularly highlight the retrievability, resonance, and resolution of Princess Leia as a visual symbol. For example, costumes not only appeal to visual media's preference for the spectacle but they also demonstrate the wearer's challenge to and negotiation of boundaries (Liao 2010, 39; Rahman, Wing-sun and Cheung 2012). Nicolle Lamerichs defines cosplay as "a form of appropriation that transforms and actualizes an existing story in close connection to a fan community and the fan's own identity" $(2011,1)$. Cosplaying Princess Leia as an expression of rebellion, therefore, allows protestors to make Leia's strength, her ability to both direct and outwit men's actions, and her fortitude in the face of great adversity their own characteristics, and to believe that having "a new hope" can truly overcome "the dark side" of the political milieu. Similarly, superimposing Leia and Rosie merges their narratives of strength in adversity, just as combining the Rebel princess with Bowie's "Rebel Rebel" establishes a challenge to the boundaries of women's roles and gendered identities.

The phenomenon of popular culture icons as protest symbols and their use throughout three years, and counting, of the Women's March, demonstrates the persistence of collective identity in a mediated environment and the rising influence of fandoms and fan cultures to create and recreate new forms of collective identification that make use of all available means of production and dissemination of fan and agitation texts. The Rebel Alliance within the Women's March demonstrates the potential of fan-based citizenship, such as that found within projects like the Harry Potter Alliance and the Star Wars Force for Change (Hinck 2019).

By adopting inclusive and viral "memetic signifiers," like Princess Leia, Women's Marchers become involved in a process of collective transfiguration which temporarily reverses the experience of isolation and commodification in media consumption. Through Princess Leia, and other Star Wars allusions, "protest participants seek recognition from their peers in the movement and declare their participation in a collective project, thereby abdicating some of their individual identity" to "become an active unit a collective aggregate that transcends their own actions" (Gerbaudo 2015, 927). As Gerbaudo has argued, such "Memetic signifiers thus constitute the rallying point of political communities that are necessarily transient, but which nonetheless need their own symbols and icons to arise and mobilize people, so to make them 
perceive their newly found sense of unity and purpose" (2015, 927-928). Or, in the words of General Leia Organa in The Last Jedi, "We have everything we need" [emphasis added].

\section{Bibliography}

Anderson, Nick. "Good thing Justice is blind.” Editorial cartoon. May 8, 2019. https://www.facebook.com/EditorialCartoons/photos/a.154224724642757/228813000458 $5541 /$ ?type $=1 \&$ theater

AZ BlueMeanie. 2008. "McCain Abandons GOP Conservative Base.” Blog for Arizona. June 5. Retrieved May 13, 2019. https://arizona.typepad.com/blog/2008/06/mccainabandons.html.

Barclay, Brigette. 2019. “'Rebellions are Built on Hope’: Women and Star Wars.” Paper presented at the Digital Frontiers conference on Realizing Resistance, Denton, TX, May 4.

Barron, John and Shawn Remulac. 2017. Trump's Titans vs. Fidget Spinner Force. Apple Valley, CA: Keenspot.

Black, Rebecca W. 2009. "Online Fan Fiction, Global Identities, and Imagination." Research in the Teaching of English 43 (4): 397-425.

Bowers, John W., Donovan J. Ochs, Richard J. Jensen, and David P. Schulz. 2010. The Rhetoric of Agitation and Control, $3^{\text {rd }}$ edition. Long Grove, IL: Waveland Press, Inc.

Bowman, Cole. 2016. "Pregnant Padmé and Slave Leia: Star Wars' Female Role Models.” In The Ultimate Star Wars and Philosophy: You Must Unlearn What You Have Learned. Edited by Jason T. Eberl and Kevin S. Decker. 161-171. Oxford: Wiley Blackwell.

Cagle, Jess. 2002. "So What's the Deal with Leia's Hair?” TIME. April 21. Retrieved May 13, 2019. http://content.time.com/time/arts/article/0,8599,232499,00.html.

Conners, Joan L. 2007. "Popular Culture in Political Cartoons: Analyzing Cartoonist Approaches." PS: Political Science and Politics 40 (2): 261-265.

Conners, Joan L. 2005. "Visual Representations of the 2004 Presidential Campaign: Political Cartoons and Popular Culture References.” American Behavioral Scientist 49 (3): 479-487.

Dougherty, Beth K. 2002. "Comic Relief: Using Political Cartoons in the Classroom.” International Studies Perspectives 3: 258-270.

Gerbaudo, Paolo. 2015. "Protest Avatars as Memetic Signifiers: Political Profile Pictures and the Construction of Collective Identity on Social Media in the 2011 Protest Wave." Information, Communication \& Society 18 (8): 916-929.

Grady, Constance. 2017. “The Women's March Shows How Intertwined Pop Culture and Politics Have Become.” Vox. January 24. Retrieved May 12, 2018. https://www.vox.com/culture/2017/1/24/14358000/womens-march-washington-popculture-politics. 
Grofman, Bernard. 1989. "Richard Nixon as Pinocchio, Richard II, and Santa Claus: The Use of Allusion in Political Satire." The Journal of Politics 51 (1): 165-173.

Grossman, Lev. 2019. "Star Wars: The Rise of Skywalker, the Ultimate Preview." Vanity Fair. May 22, 2019. Retrieved May 22, 2019.

https://www.vanityfair.com/hollywood/2019/05/star-wars-cover-story?verso=true.

Hamill, Mark. Twitter Post. January 21, 2017, 4:46 p.m. https://twitter.com/HamillHimself/status/822938477989769217

Hinck, Ashley. 2019. Politics for the Love of Fandom: Fan-Based Citizenship in a Digital World. Baton Rouge: Louisiana State University Press. Kindle edition.

Hunt, Nathan. 2003. "The Importance of Trivia: Ownership, Exclusion and Authority in Science Fiction Fandom.” In Defining Cult Movies: The Cultural Politics of Oppositional Taste. Edited by Mark Jancovich, Antonio Lázaro Reboll, Julian Stringer, and Andy Willis. 185201. New York: Manchester University Press.

Jenkins, Henry. 2006. “Quentin Tarantino's Star Wars?: Digital Cinema, Media Convergence, and Participatory Culture.” In Media and Cultural Studies KeyWorks, revised edition. Edited by Meenakshi Gigi Durham and Douglas M. Kellner, 549-576. Malden, MA: Blackwell Publishing.

King, Mary C. and Jessica L. Ridgway. 2019. "Costume Evolution During the Development of Romantic Relationships and Its Impact on the Positions of Power in the Star Wars prequel and Original Trilogies." Fashion and Textiles 6 (11): https://doi.org/10.1186/s40691-018$\underline{0167-8 .}$.

Krämer, Peter. 2012. "Fighting the Evil Empire: Star Wars, the Strategic Defense Initiative, and the Politics of Science Fiction." In Sex, Politics, and Religion in Star Wars: An Anthology. Edited by Douglas Brode and Leah Deyneka, 63-76. Plymouth, UK: Scarecrow Press.

Lamerichs, Nicolle. 2011. "Stranger Than Fiction: Fan Identity in Cosplay." Transformative Works and Cultures 7 (2011): doi:10.3983/twc.2011.0246.

Lawrence, John Shelton. 2006. "Introduction: Spectacle, Merchandise, and Influence.” In Finding the Force of the Star Wars Franchise: Fans, Merchandise, \& Critics, $2^{\text {nd }}$ ed. Edited by Matthew Wilhelm Kapell and John Shelton Lawrence, 1-20. New York: Peter Lang.

Liao, Tim F. 2010. "Visual Symbolism, Collective Memory, and Social Protest: A Study of the 2009 London G20 Protest.” Social Alternatives 29 (3): 37-43.

Loughrey, Clarisse. 2017. "Women's March: How Star Wars' Princess Leia Became a Potent Symbol of Resistance." Independent. January 22. Retrieved February 6, 2019. https://www.independent.co.uk/arts-entertainment/films/news/womens-march-onwashington-star-wars-princess-leia-carrie-fisher-a-womans-place-is-in-the-resistancea7539916.html.

Lyden, John C. 2012. "Whose Film is it Anyway? Canonicity and Authority in Star Wars Fandom." Journal of the American Academy of Religion 80 (3): 775-786. 
Matronic, Ana. Twitter post. January 21, 2017, 8:25 p.m.

https://twitter.com/msanamatronic/status/822993474635100160

McCullen, Rowan. Twitter Post. January 21, 2017, 4:49 p.m.

https://twitter.com/Robiwanobi/status/822939156573782019

Melucci, Alberto. 1995. “The Process of Collective Identity.” In Social Movements and Culture. Edited by Hank Johnston and Bert Klandermans, 41-63. Minneapolis: University of Minnesota Press.

no author. 2017. Why I March: Images from the Women's March Around the World. New York, Abrams Image. Kindle edition.

Perez, Alfred and Ben Dunn. 2017. President Pence \#1. San Antonio, TX: Antarctic Press.

Rahman, Osmund, Liu Wing-sun, and Brittany Hei-man Cheung. 2012. "Cosplay': Imaginative Self and Performing Identity," Fashion Theory 16 (3): 317-342.

Ratcliffe, Amy. 2018. "Star Wars: Women of the Galaxy Celebrates the Saga's Dynamic Female Characters - Exclusive." StarWars.com. May 30. Retrieved May 13, 2019. https://www.starwars.com/news/star-wars-women-of-the-galaxy-announced.

Rosenberg, Alyssa. 2017. “The Women's March Served Notice that Pop Culture Still Has Political Power.” Washington Post. January 25. Retrieved February 7, 2019. https://www.washingtonpost.com/news/act-four/wp/2017/01/25/the-womens-marchserved-notice-that-pop-culture-still-has-political-power/.

Shefrin, E. 2004. "Lord of the Rings, Star Wars, and Participatory Fandom: Mapping New Congruencies between the Internet and Media Entertainment Culture." Critical Studies in Media Communication 21 (3): 261-281.

The Week Staff. 2015. "7 Masterful Star Wars-themed Political Cartoons.” The Week. December 18. Retrieved May 15, 2019. https://theweek.com/articles/595049/7-masterful-starwarsthemed-political-cartoons.

Thompson, Rachel. 2018. "Professor Ranks 'Star Wars' Movies for Female Character Screen Time and the Results are Very Telling.” Mashable. May 31. Accessed May 31, 2018. https://mashable.com/2018/05/31/star-wars-female-screen-time/.

Thornton, Sarah. 1995. Club Cultures: Music, Media and Subcultural Capital. Oxford: Blackwell.

Women's March Organizers. 2017. "Preface.” In Together We Rise: Behind the Scenes at the Protest Heard Around the World. Edited by The Women's March Organizers and Condé Nast. 11-12. NP: Dey St. Kindle edition. 